KS. STANiSŁaW PIECH

\title{
KSIĘDZA PROFESORA JANA ZWIAZZKA PASJE NAUKOWE
}

Ksiądz Jan Związek przyszedł na świat 6 grudnia 1937 roku we wsi Młynki w powiecie wieluńskim w województwie łódzkim w rodzinie rolników Szczepana i Anastazji z domu Kiedos. Rodzice gospodarzyli na własnej ziemi o powierzchni 3,76 ha. Gospodarstwo położone na mało urodzajnych glebach jurajskich, typowe na tamtym terenie nie było zbyt dochodowe, pozwalało zaledwie na opłacenie podatków i utrzymanie rodziny. W okresie okupacji hitlerowskiej mały Janek mieszkał u krewnych (dziadków). Rodzice bowiem zostali wywiezieni przez Niemców na roboty przymusowe na Górnym Śląsku. Po zakończeniu działań wojennych uczęszczał do Szkoły Podstawowej w Kabałach, a potem w Załęczu Małym. Od dzieciństwa pociągała go służba Boża. Po ukończeniu szkoły podstawowej rozpoczął w 1952 roku naukę w zakresie szkoły średniej w Niższym Seminarium Duchownym w Częstochowie. Po czterech latach nauki uzyskał tam świadectwo dojrzałości. Niższe Seminarium Duchowne w Częstochowie nie posiadało w owym czasie praw państwowych. Dlatego, jako eksternista złożył ponownie egzamin dojrzałości przed Komisją Państwowa w Liceum Ogólnokształcącym im. Romualda Traugutta w Częstochowie.

Ze świadectwem maturalnym w kieszeni młody Jan pojechał do Krakowa, gdzie zapukał do furty Częstochowskiego Seminarium Duchownego przy ul. Bernardyńskiej 3 (dziś Seminarium Duchowne Diecezji Sosnowieckiej). Tam w latach 1956-1961 odbył studia filozoficzno-teologiczne, w czasie których wyróżniał się zdolnościami i zamiłowaniem do pracy naukowej. Szczególnie interesowały go dzieje Kościoła. Po ukończeniu formacji seminaryjnej przyjął święcenia kapłańskie z rąk biskupa częstochowskiego prof. dr. hab. Zdzisława Golińskiego, w uroczystość Świętych Apostołów Piotra i Pawła, 29 czerwca 1961 roku w kościele katedralnym pod wezwaniem Świętej Rodziny w Częstochowie.

DROGA NA KATEDRE UCZELNI AKADEMICKIEJ

Bezpośrednio po ukończeniu studiów seminaryjnych biskup częstochowski skierował Księdza Jana Związka na studia specjalistyczne z zakresu historii Kościoła na Wydziale Teologicznym Katolickiego Uniwersytetu Lubel- 
skiego w Lublinie. Po trzech latach studiów uzyskał w dniu 5 marca 1964 roku stopień magistra teologii w zakresie historii Kościoła na podstawie pracy $\mathrm{Ka}$ zania niedzielne Mikolaja $z$ Wilkowiecka, napisanej pod kierunkiem ks. prof. dr. hab. Mieczysława Żywczyńskiego. Ksiądz Jan nie zamierzał na tym poprzestać. „Nieśmiało, ale zacząłem myśleć o doktoracie - wspominał po latach. Chciałem zostać przy znanym zagadnieniu - kaznodziejstwo polskie. Myślałem, żeby wziąć temat - nauka o bogatych i biednych w kazaniach. Kiedyś w maju 1964 r. poszedłem do Księdza Profesora [M. Żywczyńskiego] i on mi wskazał temat - zagadnienia polityczne w kazaniach na przełomie XVI i XVII wieku w Polsce, a to szczególnie dlatego, że i jego interesowało zagadnienie stosunku kaznodziejów polskich do absolutum dominium króla Zygmunta III Wazy. Trzeba było myśleć o materiale, o źródłach i literaturze pomocniczej. Mój Mikołaj z Wilkowiecka już nie wystarczył, ale to było dużo. Na szczęście Biblioteka Katolickiego Uniwersytetu Lubelskiego miała bogate w tym względzie źródła, a resztę znalazłem gdzie indziej. I tak skompletowałem większość źródeł i literatury". Był już czwarty rok na studiach w Lublinie i wiedział, że na piaty rok studiów na pewno nie otrzyma zezwolenia swego biskupa. Materiał do rozprawy doktorskiej miał już zebrany, a jej plan zatwierdzony przez promotora, kiedy w czerwcu 1965 roku został odwołany do diecezji.

Od lipca owego roku był wychowawcą (prefektem) w Niższym Seminarium Duchownym w Częstochowie, przy ul. Piotrkowskiej 17, gdzie wychowywał się od młodych lat. Powierzono mu troskę o sprawy materialne zakładu, na których wcale się nie znał, ale wkrótce całkiem dobrze potrafił sobie z nimi radzić. Uczył tam także religii i propedeutyki filozofii marksistowskiej. W tych warunkach musiał odłożyć pracę naukową. Po kilku miesiącach potrafił sobie jednak tak zorganizować zajęcia, aby wygospodarować nieco czasu dla siebie. I wtedy kosztem należnego wypoczynku wrócił do rozprawy doktorskiej. Nauka dawała mu radość. Ona była jego pasją. „Pisałem tak jak pracę magisterską bardzo drobnym drukiem tak, iż ze strony mojego rękopisu były trzy strony maszynopisu - wspominał po latach. I pisałem dzień po dniu, czasem przerywałem, ale i wtedy myślałem co napiszę, kiedy będę miał wolny czas. Nawet podczas wyjazdów po żywność układałem sobie całe strony, widziałem je już napisane, potem było znacznie już łatwiej. A wakacje? - Wakacji nie było". Później czas ten miał już dla siebie. W czasie wakacji 1968 roku ukończył pisanie dysertacji. W latach 1966-1970 pełnił również funkcję zastępcy redaktora naczelnego „Częstochowskich Wiadomości Diecezjalnych".

Przewód doktorski na Wydziale Teologicznym Katolickiego Uniwersytetu Lubelskiego został zakończony pomyślnie i w dniu 18 czerwca 1969 roku. Ksiądz Jan uzyskał stopien doktora na podstawie rozprawy Katolickie poglady polityczno-spoleczne w Polsce na przełomie XVI i XVII wieku w świetle kazań, napisanej pod kierunkiem ks. prof. dr. hab. Mieczysława Żywczyńskiego. Recenzentami byli prof. dr hab. Janusz Tazbir i ks. doc. dr hab. Bolesław Kumor. 
W 1969 roku Ksiądz Doktor rozpoczął pracę jako archiwariusz w Archiwum Diecezjalnym w Częstochowie. Warunki pracy w archiwum w wieży kościoła katedralnego były początkowo niezwykle trudne, (pięćdziesiąt dwa stopnie krętymi schodami, a później jeszcze wyżej na wysokość czwartego piętra). Nie było tam wody ani ogrzewania. Pomieszczenia ogrzewał piecykiem elektrycznym. Było więc zimno. Dopiero później zainstalowano w archiwum elektryczne piece akumulacyjne. „Powoli doprowadzałem zbiory starodruków i archiwalne do względnego porządku - wspominał po latach swoją pracę archiwariusza. Ta praca zaczęła mi się podobać (...). Zacząłem robić pierwsze inwentarze. Na wzór podany przez ks. prof. dr. hab. Stanisława Librowskiego zinwentaryzowałem łacińskie księgi metrykalne". W tym czasie podjął także wykłady metodologii nauk i patrologii w Częstochowskim Seminarium Duchownym w Krakowie. Od 1970 roku powierzono mu nadto wykłady z zakresu historii Kościoła w tym seminarium i w Instytucie Teologicznym w Częstochowie.

Czy w tych warunkach myślał o habilitacji? „Zapewne w 1969 roku, po doktoracie, nie myślałem o przewodzie habilitacyjnym - wspominał. Zresztą moje stanowisko skarbnika w Kurii Diecezjalnej nie zachęcało do żadnej pracy naukowej". Na stanowisku skarbnika pozostawał przez półtora roku (1970-1972). Zachęcany i ponaglany przez swego kolegę ks. prof. dr. Zygmunta Zielińskiego, następcę ks. Mieczysława Żywczyńskiego na Katedrze Historii Kościoła w Czasach Nowożytnych w Instytucie Historii Kościoła na Wydziale Teologicznym Katolickiego Uniwersytetu Lubelskiego zabrał się do pisania rozprawy habilitacyjnej. „Pisałem jak dawniej pracę magisterską i doktorską bardzo gęsto na każdej stronie, oczywiście ręcznie - wspominał po latach. Czasami pisałem kilka stron dziennie, co w maszynopisie dawało kilkanaście stron, gdyż z jednej strony rękopisu miałem zwykle 3-4 strony maszynopisu. Miałem ładne teczki biurowe i podobało mi się, gdy kilka czy kilkanaście stron rękopisu wkładałem do poszczególnej teczki. Dla każdego rozdziału przeznaczałem jedną teczkę. Na odwrocie każdej strony były przypisy. Jak to się powiększało, jak miło było spojrzeć, kiedy teczka po teczce była wypełniona. Uważałem, aby rozdziały były mniej więcej jednakowe pod względem objętościowym. Jedne były przeróbką już opublikowanych artykułów, inne stanowiły nowy materiał, a wszystko zmierzało ku jednej całości. A potem zacząłem pisać na maszynie. To był rok 1982. [Pisałem] kilkanaście stron dziennie - regularnie, aż sąsiedzi mówili, że maszynę u mnie słychać - po południu, wieczorem i wcześnie rano. I faktycznie słychać było. Pisałem już dosyć szybko".

W dniu 22 grudnia 1975 roku został członkiem-współpracownikiem Towarzystwa Naukowego Katolickiego Uniwersytetu Lubelskiego w Lublinie. Od 1979 roku prowadził wykłady z historii Kościoła w Wyższym Seminarium Duchownym OO. Franciszkanów w Krakowie.

W dniu 17 listopada 1983 roku Ksiądz Zwiazek został mianowany dyrektorem Archiwum Diecezjalnego w Częstochowie. Praca w archiwum sprowadzała się nie tylko do porządkowania przechowywanych tam zbiorów, ale 
także udostępniania ich zawartości w różnego rodzaju opracowaniach i wydawnictwach. Inspiracją dla niego była działalność w tym zakresie ks. prof. dr. hab. Stanisława Librowskiego i jego publikacje na łamach czasopisma „Archiwa, Biblioteki i Muzea Kościelne". Głosił konieczność gromadzenia przez biblioteki kościelne literatury regionalnej, zwłaszcza druków ulotnych, katalogowania i ustalania proweniencji starych druków oraz szacunku dla księgozbiorów pozostałych po zmarłych księżach. Taką bibliotekę zorganizował w Archiwum Diecezjalnym.

Ksiądz Związek w dniu 7 czerwca 1984 roku uzyskał stopień naukowy doktora habilitowanego teologii w zakresie historii Kościoła na podstawie rozprawy Dzieje diecezji częstochowskiej w okresie II Rzeczypospolitej, przedstawionej Wydziałowi Teologicznemu Katolickiego Uniwersytetu Lubelskiego. Recenzentami rozprawy i całego jego dorobku naukowego byli księża: prof. dr hab. Bolesław Kumor, prof. dr hab. Hieronim Eugeniusz Wyczawski OFM i prof. dr hab. Zygmunt Zieliński. Po habilitacji biskup częstochowski dr Stanisław Nowak w dniu 6 lutego 1985 roku mianował Księdza Jana Związka rektorem Częstochowskiego Seminarium Duchownego w Krakowie.

W uroczystość Niepokalanego Poczęcia Najświętszej Maryi Panny, dnia 8 grudnia 1981 roku Ojciec Święty Jan Paweł II utworzył Papieską Akademię Teologiczną w Krakowie z trzema wydziałami: teologicznym, filozoficznym i historii Kościoła. Władze nowo powstałej uczelni zaczęły pilnie poszukiwać odpowiednich sił naukowo-dydaktycznych, szczególnie było to widoczne na organizowanym od podstaw Wydziale Historii Kościoła. Ksiądz Jan Związek od początku roku akademickiego 1986/1987 został zatrudniony jako docent na Wydziale Historii Kościoła w Papieskiej Akademii Teologicznej w Krakowie. Nominację otrzymał w kościele uniwersyteckim św. Anny, dnia 8 maja 1987 roku. Trzeba tu nadmienić, że początkowo wszystkie nominacje i dyplomy doktorów habilitowanych wręczano tylko w tym dniu. Wtedy odbywały się także promocje doktorskie. Po ustabilizowaniu się fakultetu historii Kościoła Ksiądz Związek został kierownikiem Katedry Historii Kościoła w Czasach Najnowszych oraz opiekunem specjalizacji w zakresie dziejów Kościoła powszechnego, obejmującej pięć katedr.

Od początku roku akademickiego 1990/1991 objął wykłady z zakresu historii nowożytnej w Wyższej Szkole Pedagogicznej w Częstochowie. Na Wydziale Historii Kościoła Papieskiej Akademii Teologicznej w Krakowie pełnił przez dwie kadencje obowiazki prodziekana oraz był członkiem Senackiej Komisji Regulaminowej. Równocześnie miał wykłady z zakresu patrologii w Wyższym Seminarium Duchownym OO. Paulinów i w Wyższym Seminarium Duchownym OO. Bernardynów w Krakowie.

$\mathrm{Na}$ podstawie uchwaly Senatu Papieskiej Akademii Teologicznej w Krakowie z dnia 17 czerwca 1991 roku został mianowany profesorem nadzwyczajnym „uczelnianym” na Wydziale Historii Kościoła na okres pięciu lat w wymiarze połowy etatu. W dniu 16 stycznia 1992 roku został powołany na członka Komisji Historycznej Polskiej Akademii Nauk - Oddziału w Katowicach, obejmującego cztery ówczesne województwa: katowickie, częstochow- 
skie, opolskie i bielsko-bialskie. W dniu 23 września 1992 roku Ksiądz Profesor został mianowany profesorem nadzwyczajnym w Instytucie FilozoficznoHistorycznym w Wyższej Szkole Pedagogicznej w Częstochowie, otrzymując na okres pięciu lat zatrudnienie na pełnym etacie. Zarząd Towarzystwa Naukowego Katolickiego Uniwersytetu Lubelskiego w dniu 21 maja 1991 roku mianował go swoim członkiem-korespondentem.

W dniu 8 maja 1995 roku został mianowany profesorem nadzwyczajnym historii Kościoła na Wydziale Historii Kościoła Papieskiej Akademii Teologicznej w Krakowie. Na podstawie decyzji Centralnej Komisji do Spraw Tytułu Naukowego i Stopni Naukowych z dnia 21 grudnia 1998 roku oraz Rady Naukowej Konferencji Episkopatu Polski z dnia 15 lutego 1999 roku otrzymał tytuł naukowy profesora nauk teologicznych. Nie długo później, bo w dniu 11 stycznia 2000 roku został mianowany profesorem zwyczajnym nauk teologicznych na Wydziale Historii Kościoła Papieskiej Akademii Teologicznej w Krakowie. W Wyższej Szkole Pedagogicznej od 1996 roku był przewodniczącym Komisji Uczelnianej do Spraw Odwołań, a od 1 września 1999 roku zastępcą dyrektora Instytutu Filozoficzno-Historycznego do spraw Nauki.

W czasie swej pielgrzymki do Polski papież Jan Paweł II w dniu 15 sierpnia 1991 roku odwiedził Częstochowskie Seminarium Duchowne w Częstochowie i dokonał jego poświęcenia. „Dla księdza, który wyszedł z wiejskiej izby, a teraz był rektorem Seminarium Duchownego - wspominał Ksiądz Profesor - było to ogromne przeżycie tym bardziej, iż Ojciec Święty Jan Paweł II w słowach i gestach okazał mu wiele życzliwości”. Od początku roku akademickiego 1991/1992 Częstochowskie Seminarium Duchowne zostało przeniesione z Krakowa do Częstochowy. Ksiądz Profesor w tym roku pełnił jeszcze obowiązki rektora tej uczelni. W środowisku częstochowskim starał się nawiązać kontakty naukowe z wyższymi uczelniami częstochowskimi Wyższą Szkołą Pedagogiczną i Politechniką Częstochowską. W tym czasie szczególnie angażował się w dzieło szerzenia w społeczeństwie, a zwłaszcza wśród młodzieży znajomości historii ojczystej. Wygłosił wiele referatów, popularyzujących, zwłaszcza wiedzę o Ziemi Częstochowskiej. Niektóre z nich ukazały się drukiem. W wielu ośrodkach oświatowych na terenie województwa częstochowskiego wygłaszał liczne odczyty o polskich drogach do niepodległości. Bywał bądź przewodniczącym, bądź członkiem jury w konkursach wiedzy historycznej dla młodzieży szkół średnich (klas maturalnych) w Koniecpolu.

W związku z podjęciem zajęć dydaktyczno-naukowych w Instytucie Filozoficzno-Historycznym Wyższej Szkoły Pedagogicznej w Częstochowie, 3 maja 1991 roku został członkiem Towarzystwa Naukowego Częstochowskiego, w którym przez trzy lata (1994-1997) był wiceprezesem. Na wielokrotne prośby Księdza Profesora arcybiskup Stanisław Nowak zwolnił go ze stanowiska rektora Wyższego Seminarium Duchownego z dniem 1 sierpnia 1992 roku. Od początku roku akademickiego 1992/93, po blisko ośmiu latach piastowania godności rektora mógł bez reszty poświęcić się już tylko nauce.

Ksiądz Profesor Jan Związek jest cenionym dydaktykiem, a jego dobre serce przyciaga wielu studentów na jego seminaria naukowe, które należą do 
najliczniejszych w obydwóch uczelniach. Około 250 osób uzyskało stopień naukowy magistra historii na podstawie prac napisanych $w$ jego seminariach naukowych w Papieskiej Akademii Teologicznej w Krakowie i w Wyższej Szkole Pedagogicznej w Częstochowie. Pod jego kierunkiem dziewięć osób uzyskało stopień naukowy doktora historii na Wydziale Historii Kościoła Papieskiej Akademii Teologicznej w Krakowie. Byli to: Józef Marecki OFMCap (1993), Elżbieta Cińcio SMI (1998), Jan Andrej (1999), Peter Šturak (1999), Zdzisław Gogola OFMConv. (1999), Marek Innocenty Rusecki OFM (2000), Cyril Hišem (2000), Władysław Wlaźlak (2000) i Józef Kachel OFM (2001). Wśród nich wypromował trzech księży Słowaków, dwóch z rzymskokatolickiej archidiecezji w Koszycach (J. Andrej, C. Hišem) i jeden z greckokatolickiej diecezji w Preszowie (P. Sturak). Oceniał dorobki naukowe w trzech przewodach na tzw. profesury uczelniane (ks. Wojciech Pazera w Wyższej Szkole Pedagogicznej w Częstochowie - 1999; Wiesław Franciszek Murawiec OFM - 1999 oraz do tytułu profesora ks. Kazimierz Panuś - 2001, obydwaj z Papieskiej Akademii Teologicznej). Był recenzentem w czterech przewodach habilitacyjnych, dwóch w Papieskiej Akademii Teologicznej (ks. Ludwik Królik - 1988, Józef Marecki OFMCap. - 2000), po jednym na Wydziale Humanistycznym Katolickiego Uniwersytetu Lubelskiego (Jan Mazur OSPE 1995) i na Papieskim Fakultecie Teologicznym we Wrocławiu (ks. Józef Kiedos - 1997). Recenzował dziewiętnaście rozpraw doktorskich, w tym osiem w Katolickim Uniwersytecie Lubelskim, cztery w Papieskiej Akademii Teologicznej, trzy w Akademii Teologii Katolickiej w Warszawie (dziś Uniwersytet im. Kardynała Stefana Wyszyńskiego), dwie na Uniwersytecie Šląskim w Katowicach i po jednej w Wyższej Szkole Pedagogicznej w Kielcach i na Papieskim Fakultecie Teologicznym we Wrocławiu.

Wojewoda częstochowski mianował go w 1992 roku stałym członkiem Zespołu Doradców Wojewody Częstochowskiego. Udział jego w gremium sprowadza się głównie do prezentowania aspektów historycznych różnych zjawisk w regionie częstochowskim. W dniu 27 sierpnia 2000 roku otrzymał Nagrodę Prezydenta Miasta Częstochowy za rok 2000 za całokształt pracy twórczej w dziedzinie literatury i historii.

\section{W RADOŚCI DZIELENIA SIE WIEDZA}

Ksiądz Profesor jest panem na włościach wyjątkowo rozległych. Dziedziny jego rozciagają się zarówno na poważne rozprawy ściśle naukowe, jak i na drobniejsze prace o charakterze popularnonaukowym. Nie gardzi także publicystyką. Zadziwia zarówno duża liczba opublikowanych prac jak i ich różnorodność tematyczna. W liczbie ponad 420 publikacji, w tym 10 ksiażek, wyodrębnić można wyraźnie rysujące się wątki tematyczne: biografistyka; historia Kościoła w regionie częstochowskim, którego obszar wyznaczały granice diecezji, a współcześnie archidiecezji częstochowskiej; społeczna działalność duchowieństwa i organizacji katolickich oraz archiwistyka. 
Ksiądz Jan Związek w pierwszych swoich opublikowanych pracach: Mikołaj $z$ Wilkowiecka i jego działalność kaznodziejsko-literacka, (w: Studia Historyczne, pod red. M. Żywczyńskiego i Z. Zielińskiego, t. 1, Lublin 1968, s. 9-106) oraz pomyślanej jako swoistego rodzaju kontynuacja Katolickie poglady polityczno-społeczne $w$ Polsce na przetomie XVI $i$ XVII wieku w świetle kazań, (w: Studia Kościelno-Historyczne, t. 2, Lublin 1977, s. 5-126) zwrócił uwage na kazanie jako źródło poznania zarówno zagadnień religijno-moralnych jak i społeczno-politycznych. Te ostatnie bowiem znajdowały również swoje odbicie w ówczesnym kaznodziejstwie. Pierwsza z wymienionych prac to analiza spuścizny literackiej paulina jasnogórskiego, autora Historyi o chwalebnym Zmartwychwstaniu Pańskim. Przedmiotem dociekań naukowych Autora była twórczość kaznodziejska przechowywana dotychczas głównie w postaci rękopisów w archiwach zakonnych na Jasnej Górze i na Skałce w Krakowie, mało znana poza wąskim gronem historyków zakonnych. Głównym źródłem badań był zbiór kazań Mikołaja z Wilkowiecka opublikowany w zbiorze Flores sermonum in Evangelia dominicalia (Cracoviae 1579). Twórczość ta, przypadająca na okres najsilniejszego rozwoju reformy protestanckiej w Polsce, jest jednym z argumentów świadczących o roli kaznodziejstwa katolickiego $\mathrm{w}$ polemice $\mathrm{z}$ poglądami głoszonymi przez szermierzy reformacji oraz o miejscu, jakie w niej zajmował zakon paulinów. Pośrednio świadczy o znaczeniu żywego słowa padającego $\mathrm{z}$ ambony zarówno na krakowskiej Skałce jak i w sanktuarium jasnogórskim w procesie formowania się katolicyzmu potrydenckiego. Swoistym uzupełnieniem tego studium była, wspomniana wyżej rozprawa doktorska skonstruowana na znacznie poszerzonej bazie źródłowej, obejmującej kaznodziejstwo przełomu XVI i XVII stulecia. Studia nad kaznodziejstwem XVI i XVII stulecia zaowocowały także później w postaci studium teoretyczno-metodologicznego Kazanie jako źródlo historyczne, („Folia Historica Cracoviensia”4-5:1997/1998, s. 313-330).

Ksiądz Profesor jako archiwariusz miał możliwość zapoznania się $\mathrm{z}$ wielką rolą ksiąg metrykalnych dla różnego rodzaju badań naukowych. W oparciu o opracowanie ks. prof. dr. hab. Stanisława Librowskiego o wizytacjach $\mathrm{w}$ archidiecezji gnieźnieńskiej zinwentaryzował łacińskie księgi metrykalne przechowywane w Archiwum Diecezjalnym w Częstochowie. Pracę tę zatytułowaną Inwentarz tacińskich ksiqg metrykalnych w Archiwum Diecezjalnym $w$ Częstochowie opublikował w pięciu częściach na łamach czasopisma "Archiwa Biblioteki i Muzea Kościelne" (37:1978, s. 175-220; 38:1979, s. $37-72 ; 39: 1979$, s. $5-40 ; 40: 1980$, s. $289-328)$; 41:1981, s. 53-90), oraz w oddzielnej publikacji (Lublin 1980). Ogłosił drukiem także Inwentarz ksiag konsystorskich $i$ dziekańskich $w$ Archiwum Diecezjalnym $w$ Częstochowie, („Ziemia Częstochowska” 19:1993, ss. 115). Obie te prace pozostają wprost bezcenne dla badaczy dziejów regionu częstochowskiego.

Ksiądz Profesor od lat systematycznie zajmuje się biografistyką duchowieństwa diecezji częstochowskiej. Jako archiwariusz miał bezpośredni dostęp do wytworzonych przez kancelarie Kurii Biskupiej akt personalnych po zmarłych kapłanach. Spod jego pióra wyszło blisko 170 biogramów duchow- 
nych począwszy od proboszczów po wybitne postaci biskupów częstochowskich: Teodor Kubina, Zdzisław Goliński i Stefan Bareła i błogosławionych męczenników, którzy prześladowani przez nazizm hitlerowski dali Chrystusowi ofiarą życia świadectwo miłości Maksymilian Binkiewicz i Ludwik Roch Gietyngier.

Niepoślednie miejsce w dorobku naukowym Księdza Profesora zajmuja studia poświęcone martyrologii duchowieństwa i przeszłości kościelnej regionu i diecezji częstochowskiej podczas okupacji hitlerowskiej. Świetlane postacie męczenników za wiarę, a zapewne także wspomnienia $\mathrm{z}$ dzieciństwa spowodowały, że zajął się tamtymi czasami straszliwych represji wobec polskiej ludności i Kościoła katolickiego. Owocem tego trudu pozostało kilkanaście większych lub mniejszych studiów. Najobszerniejsze z nich Martyrologium kapłanów diecezji częstochowskiej w czasie II wojny światowej, („Częstochowskie Studia Teologiczne" 4:1976, s. 185-300), w którym omówił zróżnicowane warunki działalności Kościoła na rozdartym przez okupanta niemieckiego na trzy części terytorium tej diecezji. Zarysował sylwetki 62 kapłanów zamordowanych w hitlerowskich obozach koncentracyjnych i w parafiach oraz 26 poddanych różnego rodzaju represjom. Szczegółowym problemom z tego okresu poświęcił także wiele mniejszych publikacji.

W pracach typu biograficznego ukazał wkład każdego duchownego w życie religijno-moralne i organizacyjno-społeczne parafii lub diecezji. Warto podkreślić, że opracowane przezeń biogramy w porównaniu $\mathrm{z}$ drukowanymi zwykle w urzędowych czasopismach diecezjalnych, odznaczają się solidną podstawą źródłową trzeźwą i rzeczową oceną opisywanych postaci. Zazwyczaj krótkie, trafnie charakteryzują dorobek życia przedstawianej postaci. Doskonała znajomość terenu diecezji i realiów życia duchownych pozwalały mu na traktowanie owych biogramów nie jako swoistego rodzaju panegiryków, ale jako materiał faktograficzny dla powstania monograficznego opisu dziejów Kościoła w regionie częstochowskim.

W twórczości naukowo-badawczej Księdza Profesora szczególne miejsce zajmują dzieje Kościoła w regionie częstochowskim. Najczęściej swoje pióro poświęcał historii diecezji częstochowskiej. Ksiądz Związek ,jest - jak napisał ks. prof. dr hab. Bolesław Kumor w ocenie jego dorobku naukowego do habilitacji - wytrawnym znawcą jej dziejów i problemów". W ramach tej problematyki wykazał się zadziwiającą rozpiętością zainteresowań, świadczącą nie tylko o jego rozległej erudycji w zakresie znajomości źródeł, ale także umiejętnością dostrzegania problemów wiodących zarówno w życiu kościelnym jak i społecznym. Twórca pierwszej, oryginalnej i wyczerpującej historii swojej macierzy Dzieje diecezji częstochowskiej w okresie II Rzeczypospolitej, (Częstochowa 1990), wydaje się niepodzielnie panować nad dziejami regionu. „Każde twierdzenie zostało poparte źródłem - oceniał tę monografię, znany ze swych wymagań prof. dr hab. Eugeniusz Wyczawski OFM w recenzji jego dorobku naukowego do habilitacji. - Pod tym względem Autor wykazał świetną orientację w całokształcie źródel, dotyczących opisywanej diecezji. Z jednej strony umie analizować zdarzenia i zjawiska, z drugiej poprawnie tworzyć 
syntezę. Jest krytyczny, nie gloryfikuje biskupa, (rzadkie zjawisko w pracach duchownych o biskupach), ale bezstronnie i sprawiedliwie ocenia jego działalność. Autor ma rację, zaliczając bp. [Teodora] Kubinę do wybitniejszych postaci w międzywojennym episkopacie. W wykładzie jest jasny, styl nie budzi zastrzeżeń. Widać u niego dobrą znajomość metody historycznej, wyniesioną ze znakomitej szkoły ks. Mieczysława Żywczyńskiego". Katolicki Uniwersytet Lubelski - Instytut Badań nad Polonią i Duszpasterstwa Polonijnego uchwała z dnia 9 czerwca 1992 roku przyznał mu nagrodę naukową im. Franciszka Skowyry za rok akademicki 1991/1992 za prace poświęcone dziejom posługi duszpasterskiej wśród polskich emigrantów i robotników sezonowych.

Ważne miejsce w dorobku naukowym Księdza Profesora zajmują prace poświęcone działalności oświatowej i duszpastersko-społecznej księży oraz instytucji kościelnych, bądź powstałych z inicjatywy Kościoła. Na szczególne uznanie zasługują prace poświęcone dziejom oświaty, zwłaszcza elementarnej w regionie częstochowskim. To dzięki jego badaniom wiadomo, że w okręgu częstochowskim dziekan ks. Michał Zagalski zorganizował prawie 40 szkół elementarnych, (Działalność oświatowa ks. Michala Zagalskiego w dekanacie czestochowskm w latach 1810-1825, „Summarium. Sprawozdania Towarzystwa Naukowego KUL" 4: 1975, s. 177-189), a w okręgu pajęczańskim ks. dr Józef Paulicki otwarł 15 szkół tego typu (Działalność oświatowa ks. Józefa Paulickiego w okręgu pajęczańskim (1808-1824), „Częstochowskie Wiadomości Diecezjalne" 48: 1974, s. 191-217). Biografistyka, uprawiana przezeń ze szczególną predylekcją i dominująca w jego twórczości, skłoniła go do napisania dzieła Katolickie stowarzyszenia społeczne w diecezji częstochowskiej 1925-1939, (Częstochowa 1994). Rozprawa ta, jak okazało się ze społecznego odbioru tego dzieła, była bardzo na czasie we współczesnych warunkach transformacji społeczno-ustrojowych i poszukiwania w nich miejsca dla Kościoła.

Profesor dr hab. Jan Przewłocki obserwując drogę rozwoju naukowego Księdza Jana Związka zwrócił uwagę na trzy elementy: „przede wszystkim konsekwentne dążenie do doskonalenia warsztatu naukowego, twórcze poszukiwania metodologiczne oraz stałe poszerzanie horyzontu badań naukowych"' Cechy te w połączeniu $\mathrm{z}$ wprost benedyktyńską pracowitością zaowocowały zarysowanym wyżej bogatym jego dorobkiem naukowym. Zainteresowania historyczne Księdza Profesora realizują się w podejmowaniu prac o niezwykle zróżnicowanej problematyce. Chronologicznie rozległa, (XVI-XX wiek) tematyka jego dociekań naukowych rozciaga się od badań teoretycznoarchiwalnych po żywo interesujące zagadnienia historii najnowszej z precyzyjnym zarysem faktów, wprawdzie z reguły nie zaliczanych do wielkich wątków historycznych, ale niezbędnych do ich zrozumienia i przybliżenia klimatu opisywanych wydarzeń. Badania jego obejmują przeszłość kościelną Polski południowej. Wyjątkowo tylko zapuszczał się na tereny Czech, Słowacji i Ukrainy.

W zainteresowaniach naukowych Księdza Profesora dominuje historia regionalna, „co automatycznie skłania do wydobywania wszystkich treści składających się na jego dzieje - napisał ks. prof. dr hab. Zygmunt Zieliński 
oceniając jego dorobek naukowy do profesury. Nawet drugorzędne postacie czy wydarzenia mają tu swoją wagę dla tworzenia jakiegoś continuum tradycji lokalnej. W pracach Księdza Związka dostrzega się nie tylko suchy interes naukowy, ale także umiłowanie stron rodzinnych, bez czego żadna regionalistyka nie ma racji bytu". Ksiądz Profesor potrafi z zadziwiająca łatwością przechodzić od drobiazgowych, niekiedy zbyt szczegółowych studiów do wyważonych syntez. Ta umiejętność przechodzenia od monografii materiałowej do zwięzlych syntez świadczy nader dobitnie o jego dużej rutynie badawczej i dobrym warsztacie historycznym. W swoich dociekaniach nie uchyla się przed podejmowaniem problemów trudnych, wymagających wnikliwych badań przy równocześnie dobrym rozeznaniu przyczyn zaistniałych zdarzeń. Charakterystyczna dla niego powściągliwość w ferowaniu opinii i wniosków pozwala mu na wyważone sądy o opisywanych wydarzeniach i zachowaniach ludzkich.

W ostatnich latach zaangażował się naukowo i emocjonalnie na rzecz powstania uniwersytetu w Częstochowie wraz z Wydziałem Teologicznym. Był inicjatorem wydania Stownika biograficznego Ziemi Częstochowskiej, aby wykazać, że w regionie tym żyło i działało wielu wybitnych uczonych i działaczy społecznych. Pod jego redakcją ukazała się Księga Jubileuszowa 10-lecia Instytutu Filozoficzno-Historycznego Wyższej Szkoty Pedagogicznej w Częstochowie (Częstochowa 2001), w której przedstawiono dorobek naukowy jego pracowników, co posiada duże znaczenie dla przyszłości uczelni.

Ksiądz Profesor Jan Związek w zarówno należy w środowisku krakowskim jak i częstochowskim do najlepszych znawców dziejów Kościoła w Polsce, szczególnie zaś historii życia moralno-społecznego i kulturalno-oświatowego mieszkańców Ziemi Częstochowskiej. „Merytoryczna i poznawcza wartość jego prac - zdaniem profesora Jana Przewłockiego - jest oceniana w środowisku historycznym bardzo wysoko. Zajmuje się zarówno sprawami wielkimi o powszechnym znaczeniu, ale nie stroni także od problemów pozornie drobnych, ale jakże ważnych do odtworzenia i zarejestrowania faktów z przeszłości". Fascynacja nauką w życiu Księdza Profesora owocuje ciągle nowymi pomysłami znajdującymi swoje ucieleśnienie $w$ coraz to nowych pracach. Pasja zaś $\mathrm{z}$ jaką oddaje się badaniom dziejów ojczystych podtrzymuje jego wyjątkową młodość ducha. Zapał ten udziela się licznym jego uczniom i krzepi ich na wcale nie łatwych drogach dochodzenia do Prawdy. 